\title{
TA'AWUN BASED MUHAMMADIYAH SOLIDARITY BUYING TO SUPPORT THE ECONOMY RESILIENT OF STREET VENDORS DURING COVID-19 PERIOD IN NORTH LAMPUNG \\ Agung Prihatmojo ${ }^{1}$, Badawi ${ }^{2}$, Purna Bayu Nugroho ${ }^{3}$ \\ Universitas Muhammadiyah Kotabumi
}

Agung.prihatmojo@umko.ac.id, badawi@umko.ac.id,purnabayupvz@gmail.com

\begin{abstract}
The purpose of this study was to determine the impact of solidarity buying on the economic resilience of street vendors' families during the Covid-19 pandemic.

This study uses a qualitative research method with a descriptive approach. Determination of the subject using purposive to be determined according to the purpose of the study. The subjects in this study amounted to 5 street vendors in Kotabumi, North Lampung. The technique of collecting data is semi-structured interview. Data analysis technique with steps of data reduction, data presentation, and verification. Testing the validity of the data using data triangulation.

The results of the ta'awn-based Solidarity buying research were able to increase the income of street vendors during the pandemic. The income of street vendors can increase not only from the profit of buying and selling but from the ta'awun of buyers who often overspend or give alms. Ta'awun really helps street vendors in setting aside money to pay debts. Ta' awun Mubammadiyah activities in North Lampung during the pandemic also helped fulfill the food needs of street vendors, namely the distribution of free basic-necessities to street vendors.
\end{abstract}

Keywords: Solidarity buying, street vendors, Covid-19.

\section{INTRODUCTION}

Corona virus disease 2019 (Covid-19) is a new type of disease that has never been previously identified in humans. The virus that causes Covid-19 is called SarsCoV-2. Corona virus is zoonotic transmitted between animals and humans. The spread of the Covid-19 virus through droplets of saliva/phlegm from the respiratory tract. The Covid-19 virus will spread more quickly when in a closed room or in direct contact with Covid patients. In general, people affected by the Covid-19 virus have symptoms such as severe flu, heat, fever, dizziness and loss of sense of smell. This virus can be fatal for those who suffer from respiratory disorders, will have a severe effect on lung function. 
Covid-19 has spread throughout the world, causing many deaths and economic decline in many countries. This makes many countries have to close entry and exit access (lockdown). According to (Yenti Sumarni, 2020) "the current situation experienced by the Indonesian people due to the Covid-19 has made the Indonesian economy give so much influence in various sectors. One of the sectors that was affected and felt so much was the economic sector." In Indonesia, the impact of the Covid-19 pandemic on the economy has been felt very well for entrepreneurs to street vendors (PKL). According to (Nalini, 2021) "The Corona virus pandemic is not just a health disaster, the virus known as Covid-19 has caused chaos in the economic sector. Not only big industries, the Corona virus pandemic has made SME players in Indonesia starting to get nervous."

Covid-19 forced the activities of street vendors to be limited, causing problems for the family's economic resilience. The existence of a large-scale social restriction policy (PSBB) in big cities creates a side effect that is felt by street vendors where the income of street vendors decreases due to the large-scale social restriction policy itself in which the policy regulates restrictions on the number of visitors or buyers, the distance between buyers. that must be considered is also the time limit in trading. Restrictions in other matters, namely trading, must not cause crowds to cause problems for street vendors. People who comply with PSBB do not want to buy merchandise for fear of violating the established health protocols. This makes the street vendors deserted buyers who result in losses. Sales and income of traders experienced a very significant decline due to unsold merchandise. The street vendors who trade around offices really support their daily income but they are moved so that they trade around housing which of course experience changes in income that are not comparable to what they get in the office area.

The Covid-19 virus that lasted for a long time from 2019 to today has weakened the economic resilience of the community. The impact on the economic resilience of street vendors who rely on daily income to meet their daily needs is unable to meet food and social needs. According to (Qiptiyah, 2021) "street vendors who will be threatened with losses, for example martabak traders, fried rice traders, and also other small traders who need direct interaction". The reduced income of street vendors makes it difficult for them in the economy, making it difficult to meet their food needs as well as paying rent for houses for those who are nomads in big cities. Many street vendors cannot pay the rent where they trade, cannot buy new merchandise and go out of business due to lack of capital. Economic difficulties make it difficult for street vendors to participate in online learning because parents find it difficult to get money to buy internet quota.

Preliminary research on solidarity with street vendors is research from Yaspis Edgar N. Funay in 2020, research from Ratih Probosiwi in 2021 and research from 
Rahmayati in 2021. Research (N. Funay, 2020) entitled "Indonesia in the Midst of a Pandemic: Strategy of Solidarity "Social Based on Local Tradition Values" examines the extent to which cultural values, ethics, and morals can play a role in social solidarity to maintain the survival of the Indonesian people in the midst of the current pandemic vortex. The research (Probosiwi \& Putri, 2021) entitled "Jogo Tonggo: Community Solidarity in the Era of the Covid-19 Pandemic" examines the jogo tonggo program which is implemented by adjusting the value of gotong royong in the environment so as to improve the social function of the community as social beings who help each other, and increase social solidarity. Research (Rahmayati, 2021) entitled "Solidarity Buying As The Solution Of Community Development In New Normal Era" examines solidarity buying, namely purchasing solidarity to maintain the economic chain through tolerance in purchasing goods or food from small and medium businesses during the Covid-19 pandemic.

The previous research above has not reviewed the Ta,awun-based solidarity buying to cope with the economic impact of Covid-19. The purpose of ta'awun-based solidarity buying is to help each other, help each other, give each other in realizing mutual virtue and strengthen each other according to their abilities in this context, namely buying on the basis of a sense of help. The Covid-19 phenomenon has also made Muhammadiyah call for solidarity buying based on ta'awun for street vendors (PKL) affected by Covid-19. According to (Septania, 2020) "Muhammadiyah brings the main message to all components of the nation so that collectively-collegially mobilize all resources in inflaming the spirit, thoughts, and concrete actions to help each other and work together for the good, benefit, and progress of the Indonesian nation and state. beloved". This article offers an update with the title Muhammadiyah ta'awun based solidarity buying to support the economic resilience of street vendors during the Covid-19 period in North Lampung.

\section{REVIEW OF RELATED LITERATURE}

\section{Covid-19}

The spread of the new virus, which later expanded so that it was declared a pandemic by the WHO caused anxiety and fear in the public. This fear occurs because of misunderstanding by the community. This widespread fear then causes discrimination and the emergence of inappropriate restrictions to occur in society (Chung-Ying Lin, 2020). According to (Nalini, 2021) "this virus is spreading rapidly and has spread to several countries, including Indonesia. A person can contract Covid-19 in various ways, namely: 1) Accidentally inhaling saliva splashes from a Covid-19 patient sneezing or coughing 2) Holding the mouth or nose without washing hands first after touching objects that have been splashed with saliva from a Covid-19 patient 3) Close contact with Covid-19 sufferers, for example touching or shaking hands. 


\section{Street Vendors (PKL)}

Trading businesses with small capacity, relatively small capital, and do not have their own permanent trading place usually trade around or sell on the sidewalk called street vendors. According to (Susanto, 2019) "street vendors are traders who have small capital and turnover with a low educational background, tend to occupy public spaces (roadsides, sidewalks, parks and so on) to trade, their age is generally at the age of productive and even though they sell in unofficial locations they are also subject to levies/retributions that are informal (voluntarily)".

According to (Ishlahudin, 2017) "Street vendors are one type of work in the informal sector that have a place of work that is not fixed on the road they move from one place to another throughout the day. Street vendors are found in all sectors of the city, especially at stops along bus lines, around football fields and other entertainment centers that can attract large numbers of people to buy."

\section{Economic Resilience}

National resilience is the effort of all citizens in mobilizing the power of the state to overcome problems from within and outside the country. Economic resilience is one part of national security, which is closely related to the welfare and fulfillment of the people's food, and clothing needs. According to (Wulandari, 2017) "family economic resilience is understood as a dynamic state of a family regarding persistence and strength in facing various challenges, threats, and obstacles as well as disturbances both from external and internal, directly or indirectly endangering the survival of the family economy. As the smallest unit of a country, families with strong economic resilience will create a strong economic foundation for the country."

\section{Ta'awun-Based Solidarity Buying}

Empathy and a sense of togetherness encourage the emergence of social solidarity when the Covid-19 disaster hit Indonesia. The Covid-19 pandemic on street vendors encourages the development of a sense of social solidarity into ta'awun-based solidarity buying. Humans as social beings have the instinct to help each other, loyal friends, tolerance, sympathy, and empathy for each other. According to (Qomaro Galuh, 2018) "Ta'âwun (please help) is a positive behavior that must exist in every individual to be able to live in society. Helping behavior in the Islamic perspective is a worship that has been embedded in every individual. Islam applies good morals in mu'amalah (hablu minan naas) which is done with a full sense of sincerity without expecting anything in return except for Allah alone.

According to (Zulkarnain Matandra, Abdul Wahab, 2020) "Ta'awun is an essential thing for every Muslim, because in Islam it is commanded to help each other" as stated in QS al-Maidah/5:2 as the meaning :

"And cooperate in righteousness and piety, but do not cooperate in sin and aggression. And fear Allah; indeed, Allah is severe in penalty." 
The verse above contains suggestions to help each other to others, but what needs to be underlined is to help in terms of goodness and piety, such as giving alms to people in need. In this case, solidarity buying is an act of solidarity to help street vendors by buying their merchandise even though there is no previous purchase interest but the intention to help.

\section{RESEARCH METHODOLOGY}

This study uses a qualitative research method with a descriptive approach. According to (Barlian, 2016) "qualitative research is research that uses a naturalistic approach to seek and find meaning or understanding of phenomena in a special context setting". Determination of the subject using purposive to be determined according to the purpose of the study. The subjects in this study amounted to 5 street vendors in Kotabumi, North Lampung. The collecting data technique is semistructured interview. Data analysis technique with steps of data reduction, data presentation, and verification. Testing the validity of the data using data triangulation.

\section{RESULT AND DISCUSSION}

\section{Characteristics of Street Vendors Subject}

The findings of the characteristics of street vendors in this study are information on the identity of street vendors who are the subject of this study. The street vendors who were the research subjects were aged 58-103 years old and included in the elderly group (elderly). Elderly street vendors have had a long selling time span of 20-50 years. The elderly group who still sells as street vendors is a condition that is vulnerable to family resilience. The elderly group is an age that should no longer be productive at work, because it meets the needs and to sustain life the elderly street vendors continue to be street vendors. The social condition of the research subjects consisted of various types of ethnic groups including Javanese, Lampung, and Sundanese. For the religion adopted, all research subjects adhere to Islam. While the economic conditions have a low standard of economic life.

Street vendors who are the subject of holding different types of merchandise. Subject 1 sells tiwul rice, subject 2 sells opak crackers, subject 3 sells petis fruit, subject 4 sells woven bamboo and subject 5 sells boiled peanuts. The subjects of street vendors 2 and 5 only peddle goods entrusted by other people and even they only make a small profit from selling these goods. All subjects sell on the side of the $\mathrm{road} /$ pavement, but do not settle in full. The merchant trades around but has a stop/base from the trade route. The PKL trading bases are usually in places full of visitors, but during a pandemic, places that are crowded with visitors, such as recreation areas, parks, shopping centers, are temporarily closed to break the Covid19 chain. This makes all PKL subjects in this study trade around the village. The facilities and infrastructure used to trade around street vendors are also different. Subject 1 spread out mats and baskets on the sidewalk. Subject 2 uses a bicycle to 
peddle merchandise and go around, but the bicycle is only guided by walking. Subject 3 uses a cart to sell porridge. Subject 4 uses bamboo to help carry woven bamboo in the form of a cage for laying chicken eggs. Subject 5 uses a cart to sell boiled corn.

\section{Findings on the Impact of Covid-19 on Street Vendors}

The street vendors are still looking for their fortune in selling even at the risk of being disciplined/dissolved. The call to "stay at home" and the implementation of work from home caused many street vendors to lose money because there were very few buyers. Street vendors do earn money by relying on crowds on the streets. The deserted streets make street vendors in very poor condition and some even do not find any buyers one day. Street vendors who sell food also suffer losses due to damage to food ingredients due to being stored for too long. In the midst of difficult times, street vendors continue to sell because after all, the economy for the family must continue. The results of the study show the impact of Covid-19 on all subjects of street vendors in the economic aspects as follows:

First is having decreased income. The findings in this study all subjects experienced a decrease in income during the Covid-19 pandemic. Merchandise sales are very difficult, income has decreased drastically by $50 \%$, even they have experienced no one buying merchandise. The decline in sales results has an impact on a little income, thus affecting the resilience of the street vendors' families. The average daily income of street vendors before Covid-19 was IDR 50,000 and the average daily income after Covid-19 fell to IDR 27,000.

Second is having debt. The income of street vendors has not been able to meet the daily needs and school needs of children. The necessities of life that are increasingly expensive and complex make street vendors have debts in stalls to meet their basic needs and debts to individuals for the needs of school children.

Third is difficulty fulfilling food needs. The difficult economic situation during the pandemic forced street vendors to only eat 2 times a day, even in more difficult times they only ate 1 time a day. PKL selling by walking around certainly drains energy and must get enough food intake, but when selling around street vendors only armed with mineral water. When hungry, sometimes street vendors eat their own goods but the goods they sell is only entrusted to them to be sold (owned by the boss who produces it) which means they also have to pay for it.

\section{Ta'awun-based Solidarity Buying Towards the Street Vendors}

\section{Economic Resilient}

The Covid-19 pandemic has caused the income of street vendors to decrease, selling merchandise is increasingly difficult because street vendors sell around while people stay at home, besides schools and offices implementing a work from home system. The solidarity buying movement based on ta'awun is felt to help the income of street vendors, so the form of solidarity buying is helping each other by buying 
merchandise to help the economic resilience of street vendors. According to Zulkarnain matandra 2020 "A society will be comfortable and prosperous, if in life the attitude of Ta'awun/help on each other is embedded".

Humans are social creatures who need the help of others. Sometimes humans can fulfill their needs even in excess, but sometimes they lack and need the help of others, so the attitude of mutual help should be applied to each other. In this study, Ta'awun emphasized a sense of mutual help for street vendors who were heavily affected by Covid-19. According to (Septania, 2020) "Ta'awun consists of six main aspects, namely the willingness to share, the willingness to provide assistance, cooperate, act as is, give voluntarily and provide facilities for others to provide convenience".

Muhammadiyah through MCCC and Lazis-Mu recommends ta'awun based solidarity buying which encourages residents to buy food and other needs for fellow friends or small traders who are heavily affected by Covid-19 in order to maintain economic resilience. The results of the study indicate that all subjects perceive themselves to receive solidarity buying assistance. All subjects perceive themselves to get solidarity buying assistance from buyers, such as 1) some buy goods out of solidarity, 2) some buy goods, 3) some pay with excess money, 4) there are buyers' aid in the form of food, goods to money, 5) there is a sincere buyer with the intention of helping so that he buys the goods even though he doesn't really need the merchandise. Social support in the form of solidarity buying shows that the source of social support is from the families of the people of North Lampung, with the aim of helping street vendors in difficult situations during the Covid-19 Pandemic.

From the results of the study, data on solidarity buying by the public during the Covid-19 pandemic. Data on the number of buyers with solidarity buying in 1 week (23 to 29 November 2020) in Kotabumi, North Lampung were as follows: 1) Subject 1 received solidarity in the form of solidarity buying from buyers 22 times in one week, 2) subject 2 gets solidarity in the form of solidarity buying from buyers as much as 34 times in one week, 3) subject 3 gets solidarity in the form of solidarity buying from buyers as much as 20 times in one week, 4) subject 4 get solidarity in the form of solidarity buying from buyers 15 times in one week, 5) subject 5 gets solidarity in the form of solidarity buying from buyers 19 times in one week.

From the results of research, Ta'awun-based solidarity buying is able to increase the income of street vendors. On average, in 1 day, you get 3 buyers on a ta'awun basis, this can increase the income of street vendors. The income of street vendors can increase not only from the profit of buying and selling but from the ta'awun of buyers who often overspend or give alms. The buyer's ta'awun is very helpful for street vendors in setting aside money to pay debts to shops and individuals. Street vendors sometimes get ta'awun assistance that is unexpected in number so that 
they are able to pay off their debts. Muhammadiyah Ta'awun activities in North Lampung during the pandemic also helped fulfill the food needs of street vendors, namely on Friday sharing activities, namely the distribution of free basic necessities to street vendors or people who could not afford it.

\section{CONCLUSION}

The Covid-19 pandemic has made the resilience of street vendors' families vulnerable. Street vendors are very dependent on daily income. The Covid-19 situation has made street vendors experience a decrease in income during the Covid19 pandemic. Merchandise sales were very difficult, resulting in a drastic decrease in turnover by up to $50 \%$, even they had experienced no one buying merchandise.

The results of the study indicate that all subjects perceive themselves to receive solidarity buying assistance. On average, in one day, street vendors get 3 solidarity buying. From the research results, the impact of Muhammadiyah ta'awun-based solidarity buying towards street vendors is very helpful for street vendors in North Lampung in terms of economic problems. In addition, the impact of ta'awun-based solidarity buying helps recover the psychological burden of street vendors who feel frustrated that they want to stop running their business because they don't sell, so thanks to solidarity buying they continue to sell. Muhammadiyah ta'awun-based solidarity buying can be concluded as an alternative solution to prevent the impact of Covid-19 on the economy.

\section{BIBLIOGRAPHY}

Barlian, eri. (2016). Metodologi Kualitatif dan Kuantitatif (1st ed.). Sukabina Press.

Chung-Ying Lin. (2020). Social Reaction toward the 2019 Novel Coronavirus (COVID-19). Social Health and Behavior, 0000-0002-.

Ishlahudin. (2017). Peranan Pedagang Kaki Lima Dalam Menanggulangi Tingkat Pengangguran Dalam Perspektif Ekonomi Islam Di Kota Makassar. Skripsi, 4, 9-15.

N. Funay, Y. E. (2020). Indonesia dalam Pusaran Masa Pandemi: Strategi Solidaritas Sosial berbasis Nilai Budaya Lokal. Jurnal Sosiologi Agama Indonesia (JS AI), 1(2), 107-120. https://doi.org/10.22373/jsai.v1i2.509

Nalini, S. N. L. (2021). Dampak Dampak covid-19 terhadap Usaha MIkro, Kecil dan Menengah. Jesya (Jurnal Ekonomi \& Ekonomi Syariah), 4(1), 662-669. https://doi.org/10.36778/jesya.v4i1.278

Probosiwi, R., \& Putri, A. L. (2021). Jogo Tonggo: Solidaritas Masyarakat di Era Pandemi Covid-19. SOSIO KONSEPSLA: Jurnal Penelitian Dan Pengembangan Kesejabteraan Sosia, Vol 10(02), 177-192.

Qiptiyah, M., \& Yogyakarta, U. N. (2021). Siasat Pedagang Kaki Lima di tengah Pandemi Covid-19 di Pasar Porong Kabupaten Sidoarjo. June, 0-19. 
Qomaro Galuh, W. dan A. O. (2018). Manifestasi Konsep Ta'awun Dalam Zaakwaarneming Prespektif Hukum Perikatan. Trunojoyo, 1(1), 14-25. http:/ /weekly.cnbnews.com/news/article.html?no=124000

Rahmayati. (2021). Solidarity Buying As The Solution Of Community Development In New Normal Era. Proceeding International Seminar on Islamic Studies, 2, 69-78.

Septania, S. K. (2020). Muda, Berani dan Tanpa Pamrih : Karakter Grit pada Perilaku 'Ta' awun Relawan Muda Muhammadiyah. Jurnal Sains Psikologi, 9(1), 15-25. http://journal2.um.ac.id/index.php/JSPsi/article/view/11399

Susanto, E. K. O. (2019). Pemberdayaan Pedagang Kaki Lima Di Kota Metro. Skripsi. Institut Agama Islam Negeri (Iain) Metro.

Wulandari, P. K. (2017). Inovasi Pemuda Dalam Mendukung Ketahanan Ekonomi Keluarga (Studi Kasus Pada Kampung Warna-Warni Kelurahan Jodipan, Kecamatan Blimbing, Kota Malang). Jurnal Ketahanan Nasional, 23(3), 300. https://doi.org/10.22146/jkn.28829

Yenti Sumarni. (2020). Pandemi Covid-19: Tantangan Ekonomi Dan Bisnis. Al Intaj: Jurnal Ekonomi Dan Perbankan Syariah, 6(2), 46-58.

Zulkarnain Matandra, Abdul Wahab, S. (2020). Peran Ta'awun dalam Mengentas Kemiskinan di Kota Makassar. 16, 1-16. 